\title{
Purification, cDNA cloning and expression of a cadmium-inducible cysteine-rich metallothionein-like protein from the marine sponge Suberites domuncula
}

\author{
Heinz C. Schröder ${ }^{1}$, Kateryna Shostak ${ }^{1,2}$, Vera Gamulin ${ }^{3}$, Markus Lacorn ${ }^{4}$, \\ Alexander Skorokhod ${ }^{1,2}$, Vadim Kavsan ${ }^{2}$, Werner E. G. Müller ${ }^{1, *}$ \\ ${ }^{1}$ Abteilung Angewandte Molekularbiologie, Institut für Physiologische Chemie, Universität Mainz, Duesbergweg 6. \\ 55099 Mainz, Germany \\ ${ }^{2}$ Department of Biosynthesis of Nucleic Acids, Ukrainian Academy of Sciences, Institute of Molecular Biology and Genetics, \\ 252627 Kiev, Ukraine \\ ${ }^{3}$ Department of Molecular Genetics, Institute Rudjer Boskovic, 10000 Zagreb, Croatia \\ ${ }^{4}$ Institut für Biochemie und Lebensmittelchemie, Universität Hamburg, Grindelallee 117, 20146 Hamburg, Germany
}

\begin{abstract}
During the last few years sponges have been proven to be suitable model organisms for biomonitoring programmes. Previously it was reported that the marine sponge Suberites domuncula reacts to cadmium, both under controlled laboratory conditions and in the field with an increased expression of the heat-shock protein 70 and with DNA damage. In this study it is shown that this sponge contains a cadmium-binding protein with a $\mathrm{M}_{\mathrm{r}}$ of 24000 . Cloning studies detected a gene in $S$. domuncula, termed SDMTL, which encodes a putative polypeptide, MTL_SUBDO, that shares high sequence similarity with metallothioneins (MTs) from Metazoa. The open reading frame displays a polypeptide with a calculated size of $M_{r}$ of 17103 . Phylogenetic analysis revealed that the sponge molecule, termed MT-like (MTL) protein, is related to the metazoan MTs. Under laboratory conditions, no expression of the SDMTL can be detected. After $1 d$, incubation of the sponges with cadmium (200 $\left.\mathrm{ug} \mathrm{l}^{-1}\right)$ already revealed a dramatic upregulation of the MTL gene in $S$. domuncula. Subsequent studies in the field, the area around Rovinj (Croatia), demonstrated a correlation between the environmental load with cadmium (accumulation of this metal in the animals) and the expression of the gene encoding the 'detoxifying' cadmium-binding protein, MTL, in the test animals. These data suggest that the discovered MTL gene from S. domuncula is a sensitive indicator for environmental, bioavailable cadmium.
\end{abstract}

KEY WORDS: Cadmium $\cdot$ Sponges $\cdot$ Porifera $\cdot$ Suberites domuncula $\cdot$ Croatia $\cdot$ Metallothionein $\cdot$ Biomonitoring $\cdot$ Biomarker

\section{INTRODUCTION}

Sponges (phylum Porifera) as suspension feeders are characterized by an amazingly high water-filtration rate. Some marine species filter $24000 \mathrm{l} \mathrm{kg}^{-1}$ body weight $\mathrm{d}^{-1}$ (Vogel 1977) or pump a volume of water equal to their own body volume every $5 \mathrm{~s}$ (Reiswig 1974). Hence they

\footnotetext{
*Corresponding author. E-mail: wmueller@mail.uni-mainz.de
}

must be provided with a powerful protection system against adverse compounds which are taken up from the environment. Studies revealed that sponges can cope with organic pollutants and organismic attacking invaders by (1) cellular defense systems, e.g. heat-shock proteins (Koziol et al. 1997), targeting chaperones like the 14-3-3 protein(s) (Wiens et al. 1998), multidrug resistance (MDR) (reviewed in Kurelec 1997) or thioredoxin (Wiens et al. 1999) and by (2) organismic protection, including a well-developed immune system 
(Müller et al. 1999) and bioactive secondary metabolites (Sarma et al. 1993, Proksch 1994). Recently, we also identified the second MDR-system, related to the POH1 [pad one homologoue] mechanisms (Spataro et al. 1997), which is thought to 'eliminate' pollutants via an enzymatic route (Krasko et al. 2000).

Besides organic compounds, sponges are also exposed to inorganic compounds, e.g. cadmium, that are not only hazardous for the sponges in particular but also for the ecosystem dynamics and for human health in general (Rand 1995, Clark 1997). Even though sponges, here with reference to the marine sponge Suberites domuncula, react apoptotically to high concentrations of cadmium (Wagner et al. 1998), they are able to accumulate this metal in the body to high levels. One field study in the area around Rovinj (Croatia) revealed (Müller et al. 1998) that $S$. domuncula specimens, which are exposed to $0.4 \mu \mathrm{g}$ cadmium $\mathrm{l}^{-1}$ in the surrounding sea water (Mikulic 1994), are able to accumulate this metal $\sim 20000$-fold in their bodies; similarly high levels were determined for a second sponge species Halichondria panicea (Olesen \& Weeks 1994, Hansen et al. 1995). In an earlier study we found that an increase of cadmium in $S$. domuncula causes a simultaneous decrease of zinc (Müller et al, 1998). Based on this finding we speculated that the differential capacity of the sponge to bind metals might depend on the presence of heavy-metal binding protein(s), e.g. metallothionein(s) (MT).

MTs represent a diverse family of metal-detoxifying proteins that are found in animals, plants, fungi, and prokaryotes (Hamer 1986). They are grouped according to their primary structure (Hamer 1986, Kagi \& Schaffer 1988, Unger et al. 1991) into several classes. Class I MTs have the equine renal MT as a prototype (Kagi 1993). They include all vertebrate, some invertebrate (Lerch et al. 1982) and fungal MTs (Munger et al. 1987) and are characterized by the conservation of the following patterns: Cys-Xxx-Cys, Cys-Xxx-XxxCys and Cys-Cys. Class II MTs have the sea urchin MT (Nemer et al. 1985) as an example, while Class III MTs comprise the non-translationally synthesized MTs which are found in plants and some fungi (reviewed in Unger et al. 1991). MTs in the strict sense have a molecular mass of 6000 to $7000 \mathrm{Da}_{1}$ are rich in the aa cysteine ( 23 to $33 \mathrm{~mol} \%$ ), have no aromatic aa or histidine, bind 4 to 12 atoms of metal $\mathrm{mol}^{-1}$, and are heat stable (reviewed in Rand 1995).

Here we report on the first MT from a sponge, Suberites domuncula, which was at first enriched, then cloned, and finally used for expression studies in vitro and in the field. This sponge MT-like (MTL) polypeptide follows the characteristics known from other MTs, but differs in the sense that it is composed of a tandem repeat.

\section{MATERIALS AND METHODS}

Materials. Phenylmethylsulfonyl fluoride (PMSF) was obtained from Sigma (St. Louis, MO, USA), DEAEcellulose (DE-52) from Whatman Chemical Separation Ltd. (Maidstone, UK) and Sephacryl S-100 from Pharmacia/LKB (Uppsala, Sweden). Restriction endonucleases and other enzymes for recombinant DNA techniques and vectors were obtained from Stratagene (La Jolla, CA, USA), QIAGEN (Hilden, Germany), Boehringer Mannheim (Mannheim, Germany), GibcoBRL (Grand Island, NY, USA), Amersham (Amersham, UK), USB (Cleveland, OH, USA), DUPONT (Bad Homburg, Germany), Epicentre Technologies (Madison, WI, USA) and Promega (Madison, WI, USA). Taq DNA polymerase, DIG [digoxigenin] DNA labeling kit, DIG11-dUTP, Fab fragment of anti-DIG alkaline phosphatase, and CDP [disodium 2-chloro-5-(4-methoxyspiro\{1, 2-dioxetane-3, 2' -(5'-chloro)-tricyclo[3.3.1.1 $\left.{ }^{3,7}\right]$ decan\}-4-yl)phenyl phosphate] were from Boehringer Mannheim.

Sponges. Specimens of Suberites domuncula Olivi (Demospongiae: Tetractinomorpha: Hadromerida: Suberitidae: Suberites) were collected near Rovinj (Croatia; Mediterranean Sea: Adriatic Sea) and were either immediately frozen in liquid nitrogen until analysis or further exposed to cadmium.

Determination of cadmium concentration was performed as published earlier (Müller et al. 1998).

Exposure of Suberites domuncula to cadmium. Prior to the experiments the sponges remained under controlled conditions in the aquarium for $5 \mathrm{mo}$. Then, (1) in the studies for the isolation of the MTL protein from Suberites domuncula, the sponges were exposed to $100 \mathrm{\mu g} \mathrm{l}^{-1}$ of cadmium (corresponding to $163 \mu \mathrm{g} \mathrm{l}^{-1}$ of $\mathrm{CdCl}_{2}$ ) for $5 \mathrm{~d}$. Or, (2) for the studies to determine the response to cadmium on the level of gene expression, the sponges were exposed to $200 \mu \mathrm{g} \mathrm{l}^{-1}$ of cadmium in seawater for 0 to $6 \mathrm{~d}$ in $20 \mathrm{l}$ aquaria at $17^{\circ} \mathrm{C}$ under continuous aeration as described before (Müller et al. 1998). After exposure, the sponges were immediately frozen in liquid nitrogen and stored at $-80^{\circ} \mathrm{C}$.

Enrichment of Suberites domuncula MTL. All procedures were performed at $4^{\circ} \mathrm{C}_{i}$ a modification of the procedure described by Berger et al. (1995) was used. Sponge tissue $(15 \mathrm{~g})$ was homogenized with $30 \mathrm{ml}$ of a $25 \mathrm{mM}$ of Tris/HCl buffer $(\mathrm{pH} 7.5 ; 150 \mathrm{mM} \mathrm{NaCl}$, $20 \mathrm{mM}$ 2-mercaptoethanol, $50 \mu \mathrm{M}$ PMSF) and centrifuged $\left(90 \mathrm{~min}_{i} 80000 \times g\right)$. The supernatant obtained was supplemented with $5 \mathrm{~g}$ of DEAE-cellulose and stirred at low speed for $30 \mathrm{~min}$. The DEAE-cellulose was removed by centrifugation (10 min; $1200 \times g)$; a $20 \mathrm{ml}$ aliquot of the supernatant was applied onto a Sephacryl S-100 column (size $2 \mathrm{~cm} \times 25 \mathrm{~cm}$ ) and elution with was performed with the above-mentioned 
Tris/HCl buffer at a flow rate of $5 \mathrm{ml} \mathrm{min}^{-1}$. Fractions of $5 \mathrm{ml}$ were collected and the absorbance measured at $280 \mathrm{~nm}$ to estimate the overall protein pattern.

Cadmium analysis. Cadmium-containing fractions were analyzed by atomic absorption spectrometry using a Perkin-Elmer 2380 machine (GF-AAS).

Field studies. For studies to determine the level of gene expression, Suberites domuncula specimens were taken from 5 different sites (Fig. 1A) which had been previously used in an earlier study (Müller et al. 1998). They are in the close vicinity of fixed sampling sites used in earlier environmental studies (Ugarkovic et al. 1990, Bihari \& Batel 1994) characterized by a distinct gradient of pollution. Site S-1 is a small bay at Rovinj

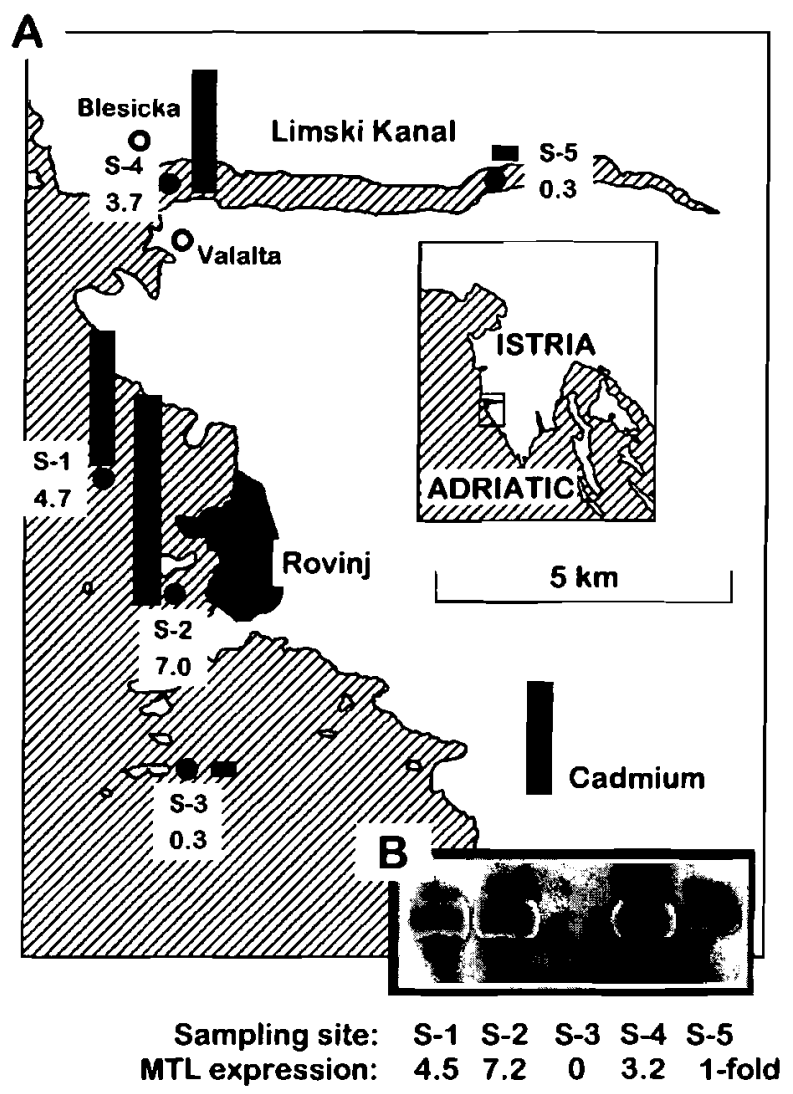

Fig. 1. Selected sites for the field study. (A) Sampling sites for Suberites domuncula in the Rovinj area (Northern Adriatic, Mediterranean Sea). The sites are termed Site S-1, Rovinj (fish cannery); Site S-2, Rovinj (harbor area); Site S-3, S. Giovanni in Pelago; Site S-4, entrance to the Limski Kanal; and Site S-5, end of the Limski Kanal. (B) Sponges were collected and RNA immediately extracted. Four $\mu \mathrm{g}$ of total RNA from sponges from each of the 5 indicated sites were analyzed. After RNA extraction, the samples were size separated and after blot transfer hybridized with the SDMTL probe. The Northern blot with the references to the sites indicated under (A) is shown in (B); further details are given in 'Materials and Inethods'. In (B) the relative level of expression of the gene for $S D M T L$ is indicated. The bars [and the numbers below] in (A) mark the concentration of cadmium in the sponges (given in $\mathrm{mg} \mathrm{kg}^{-1}$ wet weight) (influence of a fish cannery); Site S-2 is at the rim of the harbor area of Rovinj (direct influence of the urban runoff and a tobacco factory) ${ }_{i}$ Site S-3 is near the island of S. Giovanni in Pelago (uncontaminated); Site S-4 is the entrance to the Limski Kanal, placed close to the tourist camps Blesicka in the North and Valalta in the South (tourist waste) and Site S-5 is $2 \mathrm{~km}$ from the end of the Limski Kanal (uncontaminated and only occasionally under the influence of a fish farm).

Polymerase chain reaction (PCR) cloning of Suberites domuncula MT CDNA SDMTL. The complete sponge cDNAs, encoding the MTL protein MTL_ SUBDO, termed SDMTL, was isolated from the $S u b$ erites domuncula cDNA library (Kruse et al. 1997) by PCR (Ausubel et al. 1995). The degenerate forward primer, directed against the conserved aa segments found in the sequences from the MT of the crab Carcinus maenas (MT_CARMA, P55948 [Pedersen et al. 1994]; $\mathrm{aa}_{30}$ to $\mathrm{aa}_{41}$ ) 5'-TTGT/CAAA/GTGT/CGGA/G/ T/CGAA/GGAT/CTGT/CAA-3' was used in conjunction with the $3^{\prime}$-end vector-specific primer. The PCR reaction was carried out at an initial denaturation at $95^{\circ} \mathrm{C}$ for $3 \mathrm{~min}$, then 30 amplification cycles at $95^{\circ} \mathrm{C}$ for $30 \mathrm{~s}, 52^{\circ} \mathrm{C}$ for $45 \mathrm{~s}, 74^{\circ} \mathrm{C}$ for $1.5 \mathrm{~min}$, and a final extension step at $74^{\circ} \mathrm{C}$ for $10 \mathrm{~min}$. The reaction mixture was as described earlier (Wiens et al. 1998). The longest fragment of $-500 \mathrm{bp}$ was used and completed by primer walking as described by Ausubel et al. (1995). The clone obtained had a size of 713 nucleotides [nt] (excluding the poly(A) tail). The clones were sequenced using an automatic DNA sequenator (Li-Cor 4200).

Sequence comparisons. The sequences were analyzed using the computer programs BLAST (Pearson \& Lipman 1988) and FASTA (Lipman \& Pearson 1985). Multiple alignments were performed with CLUSTAL W Ver. 1.6 (Thompson et al. 1994). Phylogenetic trees were constructed on the basis of aa sequence alignments by neighbour-joining, as implemented in the 'Neighbor' program from the PHYLIP package (Felsenstein 1993). The distance matrices were calculated using the Dayhoff PAM matrix model as described by Dayhoff et al. (1978). The degree of support for internal branches was further assessed by bootstrapping (Felsenstein 1993). The graphic presentations were prepared with GeneDoc (Nicholas \& Nicholas 1997).

Northern blotting. RNA was extracted from liquidnitrogen pulverized sponge tissue with TRIzol Reagent (GibcoBRL) as recommended by the manufacturer. An amount of $4 \mu \mathrm{g}$ of total RNA was electrophoresed through a formaldehyde/agarose gel and blotted onto a Hybond $\mathrm{N}^{+}$membrane following the manufacturer's instructions (Amersham). Hybridization experiments were performed with the following probes: the $\sim 500 \mathrm{bp}$ fragment of SDMTL from Suberites domuncula and 
the $S$. domuncula $\beta$-tubulin (authors' unpubl. data) $S D B T U B(\sim 800 \mathrm{bp})$. Hybridization was performed with the antisense DIG-labeled probes at $42^{\circ} \mathrm{C}$, following the instructions of the manufacturer (Boehringer) and as recently described by Krasko et al. (1999). After washing, DIG-labeled nucleic acid was detected with anti-DIG Fab fragments and visualized by the chemiluminescence technique using CDP-Star. The signals of the Northern blots were quantitated by the chemiluminescence procedure (Stanley \& Kricka 1990). The screen was scanned with a GS-525 Molecular Imager (Bio-Rad). The relative values for the expressions of the SDMTL and SDBTUB genes in S. domuncula tissue were correlated with the intensities of the bands measured for the expression of the tubulin gene.

\section{RESULTS}

\section{Procedure for the enrichment of MTL}

Sponge extracts were prepared and adsorbed to DEAE-cellulose as described in 'Materials and methods'. Subsequently, the resulting supernantant was subjected to gel-permeation chromatography and the cadmium content in each fraction was analyzed by atomic absorption. The cadmium-binding fractions eluted from the Sephacryl column at a position equivalent to about $24 \mathrm{kDa}$ (Fig. 2). The protein fraction with

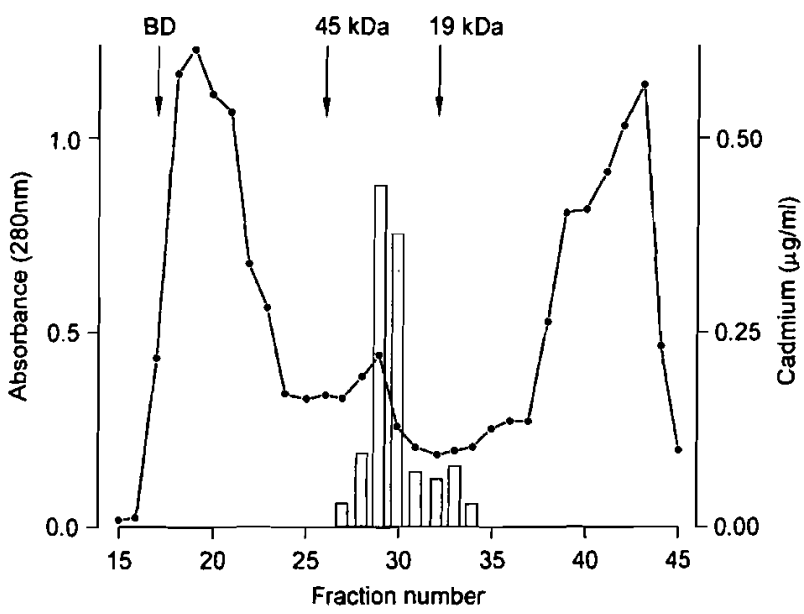

Fig. 2. Enrichment of MTL protein in Suberites domuncula tissue. Sephacryl S-100 column chromatography of S. domuncula extract, which had been pretreated by DEAE-cellulose adsorption. An aliquot was applied to the gel-permeation chromatography column as described in 'Materials and methods'. The fractions were analyzed at an absorbance at $280 \mathrm{~nm}(\bullet-\circ)$ and for cadmium concentration (open bars). Calibration of the column was performed with Blue Dextran $\left(\mathrm{M}_{\mathrm{r}} 2000 \mathrm{kDa}\left[\mathrm{V}_{\mathrm{o}}\right]_{;} \mathrm{BD}\right)$, chicken egg albumin $(45 \mathrm{kDa})$ and myoglobin (18.5 kDa) in parallel runs the highest cadmium content (fraction 29) consisted of $0.45 \mu \mathrm{g}$ cadmium $8 \mathrm{mg}^{-1}$ protein; determined according to Lowry et al. (1951). Taking into account the estimated $\mathrm{M}_{\mathrm{r}}$ of 24000 a total of about $1.4 \mathrm{~g}$ of atom cadmium is bound per mol of cadmium-binding protein in fraction 29. For the molluscan MTs a binding capacity of $7 \mathrm{~g} \mathrm{~mol}^{-1}$ was measured (Roesijadi et al. 1989), suggesting that the sponge preparation was-as expected - not yet pure. Cadmium could not be measured in any other fractions than those between 27 and 34 .

\section{Cloning of the MTL cDNA SDMTL from Suberites domuncula}

The cDNA encoding the MTL from Suberites domuncula was isolated and characterized. The $713 \mathrm{bp}$ long sequence has an open reading frame of $516 \mathrm{nt}$. Northern blot analysis revealed a single band of $0.9 \mathrm{~kb}$, indicating that the clone is of full length (Fig. 3).

The predicted translation product of $172 \mathrm{aa}$, named MTL_SUBDO (Fig. 4), has a calculated size of $M_{r} 17103$ and a pI of 7.69 (PC/GENE Data Banks 1995). The instability index is 44.26 , suggesting that the sponge polypeptide is unstable (PC/GENE Data Banks 1995). Thirty Cys-rich patterns, characteristic for MTs of Class I are present in the sponge sequence (Fig. 4).

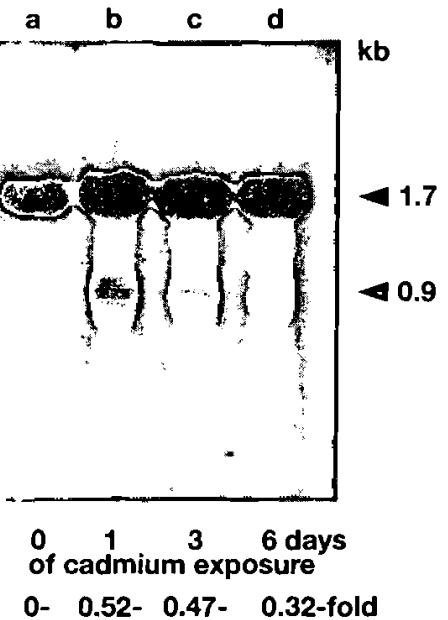

MTL expression:

0 - $0.52-0.47-0.32$-fold

Fig. 3. Effect of cadmium on the expression of the sponge SDMTL. Tissue samples were incubated for $0 \mathrm{~d}$ (lane a), $1 \mathrm{~d}$ (lane b), $3 \mathrm{~d}$ (lane c) or $6 \mathrm{~d}$ (lane d) in the presence of $200 \mu \mathrm{g}$ $\mathrm{ml}^{-1}$ of cadmium. Northern blot analyses to estimate the level of expression of the genes were then performed using the probes for the MTL protein, SDMTL. RNA was extracted and $4 \mu \mathrm{g}$ of total RNA was size separated; after blot transfer hybridization was performed with the SDMTL (signal at $0.9 \mathrm{~kb}$ ) and the SDBTUB probe $(1.7 \mathrm{~kb})$. The intensities of the transcripts for SDMTL are correlated with the expression of $\beta$-tubulin (probe added together with SDMTL during the hybridization procedure) 


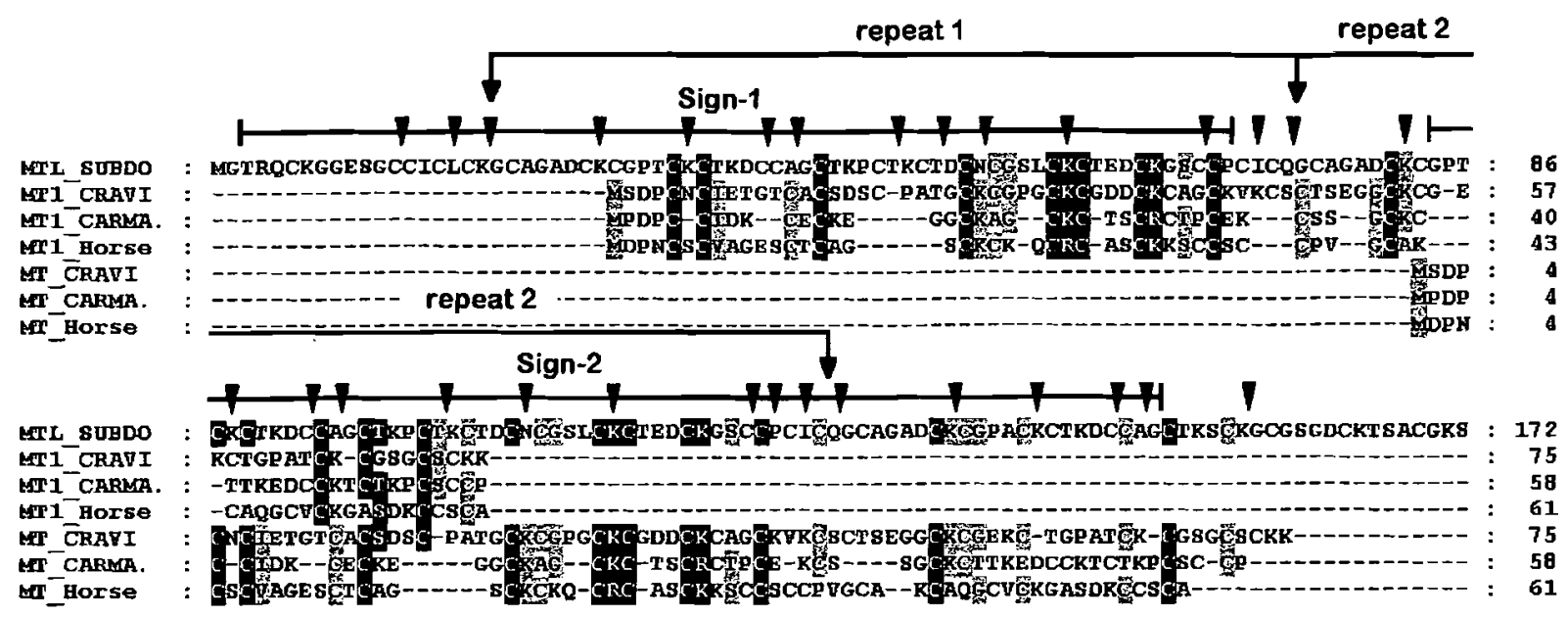

Fig. 4. Deduced MTL protein from Suberites domuncula. Alignment of the $S$. domuncula MTL protein (MTL_SUBDO) with the corresponding MT sequences from the oyster Crassostrea virginica (MT_CRAVI, accession number P23038 [Unger et al. 1991]), the crab Carcinus maenas (MT_CARMA, P55948 [Pedersen et al. 1994]) and the horse MT 1B (MT_HORSE, SMHOB [Kojima et al. 1976]). These 3 sequences, from the oyster, the crab and the horse, were aligned both with the $\mathrm{NH}_{2}$-terminal as well as the $\mathrm{COOH}$-terminal portion of the sponge MTL. Similar (with respect to physico-chemical properties) amino acids in all sequences are given in white on black and those in at least 3 sequences in black on gray. The characteristic Cys patterns: Cys-Xxx-Cys, Cys-Xxx-Xxx-Cys and Cys-Cys are indicated (arrow head). The location of the 2 vertebrate MT signatures (Sign-1 and Sign-2 $[\longmapsto]$ ) and the 2 repeats (bordered by arrows) are delimited

Likewise characteristic for MTs is the aa compositon of the sponge polypeptide; $32 \mathrm{~mol} \%$ of Cys and the absence of aromatic aa and of His (PC/GENE Data Banks 1995; Prosite). Two vertebrate MT signatures are present $\left(\mathrm{aa}_{2}\right.$ to $\mathrm{aa}_{71}$ and $\mathrm{aa}_{84}$ to $\left.\mathrm{aa}_{151}\right)$. The fact that the sponge MT polypeptide comprises 2 identical repeats, ranging from $\mathrm{aa}_{20}$ to $\mathrm{ad}_{74}$ and from $\mathrm{aa}_{74}$ to $\mathrm{aa}_{129}$ (Fig. 4), is interesting. Since such an arrangement has not been described in other MTs, we termed the sponge sequence, a MTL protein; Fig. 4.

\section{Phylogenetic position of Suberites domuncula MTL}

The sponge MTL polypeptide is composed of 2 identical repeats. To demonstrate this fact the 3 sequences used for the alignment with the sponge MTL, the MT from the oyster Crassostrea virginica (Unger et al. 1991), the crab Carcinus maenas (Pedersen et al. 1994) and the horse (Kojima et al. 1976) were aligned both with the $\mathrm{NH}_{2}$-terminal as well as the $\mathrm{COOH}$-terminal portion of the sponge MTL (Fig. 4).

A databank search with the Suberites domuncula polypeptide MTL_SUBDO revealed similarity to metazoan MTs. The phylogenetic tree, constructed after alignment of the 4 sequences denoted in Fig. 4 together with the protostomian sequence from Caenorhabditis elegans, the mussels Mytilus edulis and Dreissena polymorpha, and the oyster Crassostrea virginica, as well as the deuterostomian MTs (from sea urchin Sterechinus neumayeri, carp Cyprinus carpio, frog Xenopus laevis, pigeon, human, mouse and bovine), revealed that the sponge MTL polypeptide forms the basis of all metazoan MTs (Fig. 5). It is notable that the sea urchin sequence clusters together with the protostomian sequences and not with the deuterostomian MTs. Evolutionarily more distantly related is the fungal MT (related) from Candida glabrata. The described cysteine-rich protein from the earthworm Enchytraeus buchholzi forms a separate branch and groups with the chosen outgroup, the plant MTL sequence from Arabidopsis thaliana.

\section{Expression of SDMTL in Suberites domuncula tissue after cadmium exposure}

Sponges used for these studies were kept in an aquarium for $5 \mathrm{mo}$ in order to eliminate potential uncontrolled effects of heavy metal. As a concentration for the cadmium exposure studies $200 \mu \mathrm{g} \mathrm{l}^{-1}$ was selected. In a previous study this concentration was found to be suitable for the detection of a response of the sponge Halichondria panicea in in vitro experiments (Hansen et al. 1995). Tissue samples from Suberites domuncula were taken after 0 to $6 \mathrm{~d}_{i}$ then the level of expression of SDMTL was determined by Northern Blot experiments. The results revealed that in the absence of cadmium, no expression of the gene encoding the MTL can be measured (Fig. 3). However, already after an incubation of $1 \mathrm{~d}$ in the presence of cadmium the expression of SDMTL increased strongly 


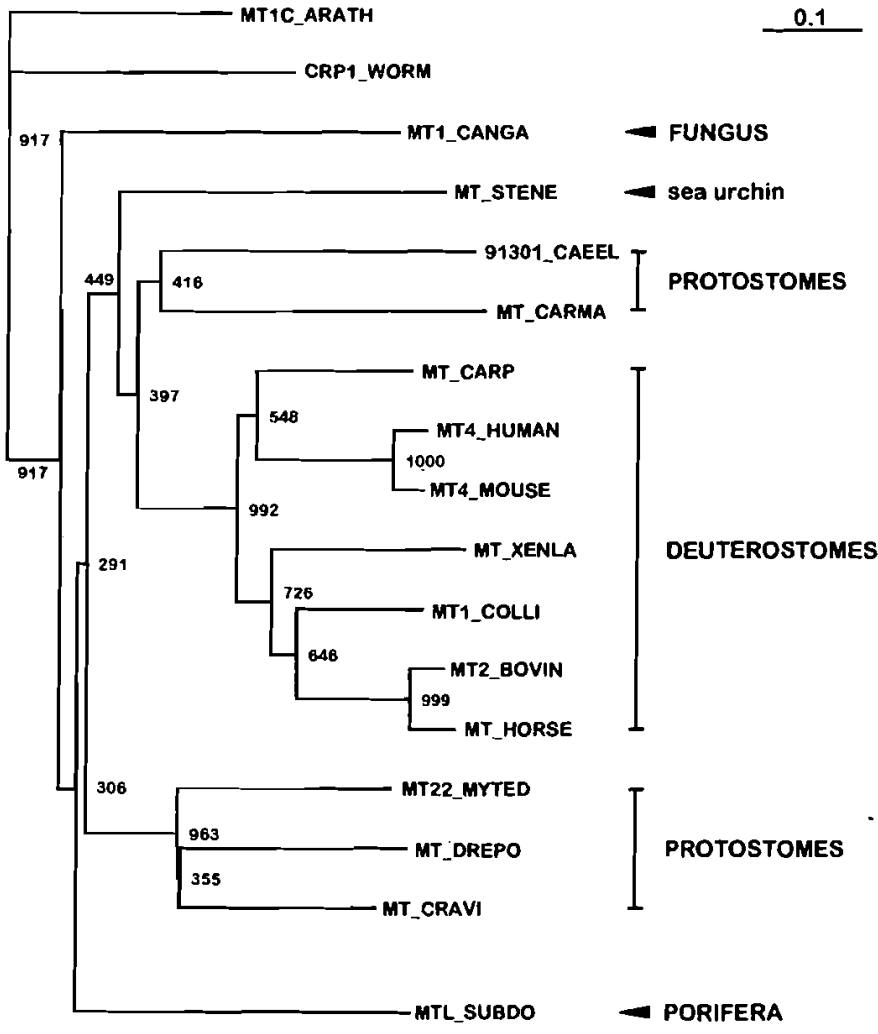

Fig. 5. Phylogenetic analysis of the sponge MTL protein. Rooted phylogenetic tree, constructed after alignment of the 4 sequences denoted under Fig. 4 together with the protostomian sequence from Caenorhabditis elegans (91301_CAEEL, CAA91301 [Wilson et al. 1994]), crab, the MT 20-II from the mussels Mytilus edulis (MT22_MYTED, P80252 [Mackay et al. 1993]), and Dreissena polymorpha (MT_DREPO, Q94550, [Scekan et al. 1996]) and the oyster, the deuterostomian MTs from the carp Cyprinus carpio (MT_CARP, AAB61577 [Chan \& Chan 1997]), the frog Xenopus laevis (MT_XENLA, Q05890 [Saint-Jacques \& Seguin 1993]), the pigeon type-I (MT1_COLLI, P15786 [Lin et al. 1990]), human type-IV (MT4_HUMAN, P47944 [Quaife et al. 1994]), mouse type-IV (MT4_MOUSE, P47945 [Quaife et al. 1994]), bovine type-II (MT2_BOVIN, P09579 [Munger et al. 1985]) and from horse as well as from the sea urchin Sterechinus neumayen (MT_STENE, P55953 [Scudiero et al. 1997]). In addition, the MT (related) sequences from the fungus Candida glabrata (MT1_CANGA, P15113 [Mehra et al. 1989]) and the cysteinerich protein CRP1 from the earthworm Enchytraeus buchholzi (CRP1_WORM, A55035 [Willuhn et al. 1994]) have been included. The plant MTL sequence from Arabidopsis thaliana (MT1C_ARATH, Q38804 [Zhou \& Goldsbrough 1995]) was used as outgroup. The analysis was performed by neighbourjoining as described in 'Materials and methods'. The numbers at the nodes are an indication of the level of confidencegiven in percentage-for the branches as determined by bootstrap analysis (1000 bootstrap replicates). The scale bar indicates an evolutionary distance of 0.1 aa substitutions per position in the sequence

and thereafter reached the maximum; at Days 3 and 6 the expression slowly reduced. On the same blot the $\beta$-tubulin probe was added; no significant differences were seen on comparing the different RNA samples, confirming that the same amount of RNA was applied (Fig. 3).

\section{Correlation of SDMTL expression with the cadmium content in the sea}

After having established that the expression of the SDMTL gene depends on the presence of cadmium under controlled laboratory conditions it was tempting to elucidate if the level of expression varies in sponges taken from defined sites from the sea as well. Those sites that had also recently been selected for the determination of the cadmium concentration in the same sponge species (Müller et al. 1998) were used. The analytical data by Müller et al. (1998) revealed that (S. Giovanni in Pelago) the level of cadmium in the sponges is lowest at Site S-3, with $0.29 \mathrm{mg} \mathrm{kg}^{-1}$. Increasing levels of cadmium have been determined: Site S-5, end of the Limski Kanal $\left(0.32 \mathrm{mg} \mathrm{kg}^{-1}\right)<$ Site S- 4 , entrance to the Limski Kanal $\left(3.7 \mathrm{mg} \mathrm{kg}^{-1}\right)<$ Site S-1, Rovinj close to the fish cannery $\left(4.7 \mathrm{mg} \mathrm{kg}^{-1}\right)<$ Site S-2, Rovinj at

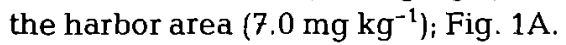

Parallel with the determination of cadmium concentrations in the sponges collected from the selected sites, the level of SDMTL expression was determined. The experiments revealed that at Site S-3 no transcripts from the SDMTL have been detected. In areas of higher cadmium load transcripts of SDMTL are detected; the intensity of the band, which reflects the steady-state level of the SDMTL, increases from Site S-5 (1-fold expression [arbitrary unit]) in the following order: < Site S-4 (3.2-fold) < Site S-1 $(4.5$-fold) and < Site S-2 (7.2-fold); Fig. 1B. These results demonstrate a strong correlation between the environmental load with cadmium (accumulation of this metal in the sponges) and the expression of the gene encoding the 'detoxifying' cadmium-binding protein, MTL, in the test sponge.

\section{DISCUSSION}

The concentration of cadmium in marine sponges collected from the natural environment varies between 0.1 to $10 \mu \mathrm{g} \mathrm{g}^{-1}$ body weight (Olesen \& Weeks 1994, Hansen et al. 1995, Müller et al. 1998); these are levels which are also found in other organisms from the marine fauna (Kennish 1994). If sponges, e.g. the species Halichondripa panicea or Suberites domuncula, are exposed to high levels of cadmium ( 1 to $5 \mu \mathrm{g} \mathrm{ml}^{-1}$ ) (Hansen et al. 1995, Müller et al. 1998) they accumulate this metal by a factor of up to 20000 -fold. Since the rate and extent of cadmium accumulation in sponges is 
directly proportional to the dissolved metal in the surrounding medium (Hansen et al. 1995) these sponges can be used as sensitive bioindicator organisms to assess anthropogenic cadmium pollution in the environment. One major cadmium detoxification pathway, which prevents major deleterious effects both in human and in sea animals (Clark 1997), is the induction of cadmium-binding proteins with the MTs as the best studied members.

ln a recent field study it was demonstrated that the content of cadmium in Suberites domuncula correlates with the level of pollution in the surrounding medium (Müller et al. 1998). In addition, it was measured that further exposure of the sponge to cadmium results in (1) a high accumulation of this metal in the body and also (2) in an increased DNA damage and in expression of the heat-shock protein 70 (Müller et al. 1998). We speculated that the accumulation of cadmium in this sponge is due to an induction of MTs. In the present study this assumption was supported by the demonstration that a cadmium-binding protein with a size of $24 \mathrm{kDa}$ is present in this sponge. Furthermore, a cDNA was isolated which potentially encodes a calculated polypeptide with a size of 17103 , which was termed MTL. Interestingly, we found that $S$. domuncula MTL is - in spite of the certainly close relationship to other MTs-different from the other known metazoan MTs in 2 aspects. Firstly, the sponge MTL is larger, $\sim 20 \mathrm{kDa}$, in comparison with MTs from Metazoa, which are characterized by a molecular mass of 6 to $7 \mathrm{kDa}$ (Kojima 1991). The sponge MTL represents a tandem duplicated polypeptide composed of 2 parts which are highly related to metazoan MTs. This finding is not too surprising in view of our earlier studies, which revealed that the domain composition and the degree of domain duplication in the sponge genome is unusually complex in comparison to other metazoan phyla (reviewed in Müller 1997, 1998).

The second distinction between the sponge MTL and the metazoan MTs, which are usually constitutively expressed, especially in tissue undergoing growth and differentiation (Brady et al. 1982), is the fact that the sponge MTL is an inducible protein. In controlled experiments in aquaria it could be established that the expression of the sponge SDMTL gene is - if at allextremely low and not detectable under the methods used. However, already after an incubation period of $1 \mathrm{~d}$ in the presence of $200 \mu \mathrm{g} \mathrm{ml}^{-1}$ of cadmium, the expression of $S D M T L$ gene was already dramatically upregulated. This finding underscores the usefulness of the sponge MTL as a biomarker for the load with anthropogenic cadmium in the sea. In addition, the Suberites domuncula MTL protein has a calculated 'instability index' of 44.26 , a value which is indicative of unstable proteins. Another cadmium-binding pro- tein has been described from an earthworm (Willuhn et al. 1994), which does not group to the MTs but also reacts in exposure studies to cadmium with a strong upregulation of gene expression.

In the crucial field experiment using the same study sites as those previously selected by Müller et al. (1998) for the determination of the response of Suberites domuncula to environmental load in the field, the level of $S D M T L$ in tissue from $S$. domuncula was determined. The results unequivocally show that the level of SDMTL expression in those sponges correlate with the load of cadmium in the environment (accumulation of this metal in the sponges).

Taken together, the studies reported here demonstrate that the discovered MTL gene from Suberites domuncula, $S D M T L$, is a sensitive indicator for environmental cadmium, both under controlled laboratory conditions and in field investigation. Even thought a direct determination of cadmium appears to be a more sensitive parameter for the load with this heavy metal, the data shown here indicate that the SDMTL gene can also be considered to be a reliable candidate for monitoring studies of bioavailability of cadmium.

Acknowledgements. This work was supported by grants from the European Commission ['BIOMARK' and 'UVTOX'] and the International Human Frontier Science Program [RG-333/ 96-M]. The sequence reported here was deposited in the European Molecular Biology Laboratory data base under the accession number AJ245813.

\section{LITERATURE CITED}

Ausubel FM, Brent R, Kingston RE, Moore DD, Smith JA, Seidmann JG, Struhl K (1995) Current protocols in molecular biology. John Wiley and Sons, New York

Berger B, Hunziker PE, Hauer CR, Birchler N, Dailinger R (1995) Mass spectrometry and amino acid sequencing of two cadmium-binding metallothionein isoforms from the terrestrial gastropod Arianta arbustorum. Biochem J 311: 951-957

Bihari N, Batel R (1994) Alkaline elution of mussel DNA as a tool for determination of environmental contamination by genotoxins. ln: Müller WEG (ed) Use of aquatic invertebrates as tools for monitoring of environmental hazards. Gustav Fischer-Verlag, Stuttgart, p 35-48

Brady FO, Webb M, Mason R (1982) Zinc and copper metabolism in neonates: role of metallothionein in growth and development in the rat. Dev Toxicol Environ Sci 9:77-98

Chan PC, Chan KM (1997) Direct submission to the European Molecular Biology Laboratory data base (on 5 May 1997)

Clark RB (1997) Marine pollution. Clarendon Press, Oxford

Dayhoff MO, Schwartz RM, Orcutt BC (1978) A model of evolutionary change in protein. In: Dayhoff MO (ed) Atlas of protein sequence and structure. Nat Biomed Res Foundation, Washington, DC, p 345-352

Felsenstein J (1993) PHYLIP, Version 3.5. University of Washington, Seattle

Hamer DH (1986) Metallothionein. Annu Rev Biochem 55: 913-951 
Hansen IV, Weeks JW, Depledge MH (1995) Accumulation of copper, zinc, cadmium and chromium by the marine sponge Halichondria panicea Pallas and the implications for biomonitoring. Mar Pollut Bull 31:133-138

Kagi JHR (1993) Evolution, structure and chemical activity of class I metallothioneins: an overview. In: Suzuki KT, Imura N, Kimura M (eds) Metallothioneins. Birkhäuser Verlag, Basel, p 29-56

Kagi JHR, Schaffer A (1988) Biochemistry of metallothionein. Biochemistry 27:8509-8515

Kennish MJ (ed) (1994) Practical handbook of marine science CRC Press, Boca Raton

Kojima Y (1991) Definitions and nomenclature of metallothioneins. Methods Enzymol 205:8-10

Kojima Y, Berger C, Vallee BL, Kagi JHR (1976) Amino-acid sequence of equine renal metallothionein-1B. Proc Natl Acad Sci USA 73:3413-3417

Koziol C, Batel R, Arinc E, Schröder HC, Müller WEG (1997) Expression of the potential biomarker heat shock protein 70 and its regulator, the metazoan DnaJ homolog, by temperature stress in the sponge Geodia cydonium. Mar Ecol Prog Ser 154:261-268

Krasko A, Schröder HC, Perovic S, Steffen R, Kruse M, Reichert W, Müller IM, Müller WEG (1999) Ethylene modulates gene expression in cells of the marine sponge Suberites domuncula and reduces the degree of apoptosis. $\mathrm{J}$ Biol Chem 274:31524-31530

Krasko A, Kurelec B, Batel R, Müller IM, Müller WEG (2000) The potential multidrug resistance gene $P O H L$ : an ecological relevant indicator in marine sponges. Environ Toxicol Chemistry (in press)

Kruse M, Müller IM, Müller WEG (1997) Early evolution of metazoan serine/threonine and tyrosine kinases: identification of selected kinases in marine sponges. Mol Biol Evol 14:1326-1334

Kurelec B (1997) A new type of hazardous chemical: the chemosensitizers of multixenobiotic resistance. Environ Health Perspect 105:855-860

Lerch K, Ammer D, Olafson RW (1982) Crab metallothionein. Primary structures of metallothioneins 1 and 2.J Biol Chem 257:2420-2426

Lin LY, Lin WC, Huang PC (1990) Pigeon metallothionein consists of two species. Biochim Biophys Acta 1037:248-255

Lipman DJ, Pearson WR (1985) Rapid and sensitive protein similarity searches. Science 277:1435-1441

Lowry OH, Rosebrough NJ, Farr AL, Randall RJ (1951) Protein measurement with the folin phenol reagent. J Biol Chem 193:265-275

Mackay EA, Overnell J, Dunbar B, Davidson I, Hunziker PE, Kagi JH, Fothergill JE (1993) Complete amino acid sequences of five dimeric and four monomeric forms of metallothionein from the edible mussel Mytilus edulis. Eur J Biochem 218:183-194

Mehra RK, Garey JR, Butt TR, Gray WR, Winge DR (1989) Candida glabrata metallothioneins. Cloning and sequence of the genes and characterization of proteins. J Biol Chem $264: 19747-19753$

Mikulic N (ed) (1994) Monitoring programme of the Eastern Adriatic Coastal Area (1983-1991). United Nations Environmental Programme, MAP Technical Reports Ser 86, p 275

Müller WEG (1997) Origin of metazoan adhesion molecules and adhesion receptors as deduced from their cDNA analyses from the marine sponge Geodia cydonium. Cell Tissue Res 289:383-395

Müller WEG (1998) Origin of Metazoa: sponges as living fossils. Naturwissenschaften 85:11-25
Müller WEG, Batel $R$, Lacorn $M$, Steinhart $H$, Simat $T$, Lauenroth S, Hassanein H, Schröder HC (1998) Accumulation of cadmium and zinc in the marine sponge Suberites domuncula and its potential consequences on single-strand breaks and on expression of heat-shock protein: a natural field study. Mar Ecol Prog Ser 167:127-135

Müller WEG, Blumbach B, Müller IM (1999) Evolution of the innate and adaptive immune systems: relationships between potential immune molecules in the lowest metazoan phylum [Porifera] and those in vertebrates. Transplantation 68:1215-1227

Munger K, Germann UA, Beltramini M, Niedermann D, Baitella-Eberle G, Kagi JH, Lerch K (1985) (Cu, Zn)-metallothioneins from fetal bovine liver. Chemical and spectroscopic properties. J Biol Chem 260:10032-10038

Munger K, Germann UA, Lerch K (1987) lsolation and regulation of expression of the Neurospora crassa copper metallothionein gene. J Biol Chem 262:7363-7367

Nemer M, Wilkinson DG, Travaglini EC, Sternberg EJ, Butt TR (1985) Sea urchin metallothionein sequence: key to an evolutionary diversity. Proc Natl Acad Sci USA 82: 4992-4994

Nicholas KB, Nicholas HB Jr (1997) GeneDoc: a tool for editing and annotating multiple sequence alignments. Version 1.1.004. Distributed by the author

Olesen TME, Weeks JM (1994) Accumulation of Cd by the marine sponge Halichondria panicea Pallas: effects upon filtration rate and its relevance for biomonitoring. Bull Environ Contam Toxicol 52:722-728

PC/GENE Data Banks (1995) CD-ROM [EMBL, Swiss Prot]; Release 14.0. IntelliGenetics, Inc, Mountain View, CA

Pearson WR, Lipman DJ (1988) Improved tools for biological sequence comparison. Proc Natl Acad Sci USA 85: 2444-2448

Pedersen KL, Pedersen SN, Hojrup P, Andersen JS, Roepstorff P, Knudsen J, Depledge MH (1994) Purification and characterization of a cadmium-induced metallothionein from the shore crab Carcinus maenas (L.). Biochem J 297: 609-614

Proksch P (1994) Defensive roles for secondary metabolites from marine sponges and sponge-feeding nudibranchs Toxicon 32:639-655

Quaife CJ, Findley SD, Erickson JC, Froelick GJ, Kelly EJ, Zambrowicz BP, Palmiter RD (1994) Induction of a new metallothionein isoform (MT-IV) occurs during differentiation of stratified squamous epithelia. Biochemistry 33: $7250-7259$

Rand GM (1995) Fundamentals of aquatic toxicology. Taylor \& Francis, Washington

Reiswig HM (1974) Water transport, respiration, and energetics of three tropical marine sponges. J Exp Mar Biol Ecol 14:231-249

Roesijadi G, Kielland S, Klerks P (1989) Purification and properties of novel molluscan metallothioneins. Arch Biochem Biophys 272:403-413

Saint-Jacques E, Seguin C (1993) Cloning and nucleotide sequence of a complementary DNA encoding Xenopus laevis metallothionein: mRNA accumulation in response to heavy metals. DNA Cell Biol 12:329-340

Sarma AS, Daum T, Müller WEG (1993) Secondary metabolites from marine sponges. Akademie gemeinnütziger Wissenschaften zu Erfurt, Ullstein-Mosby Verlag, Berlin

Scekan SR, Engelken J, Hildebrandt A (1996) Direct submission to EMBL/GENBANK/DDBJ data banks

Scudiero R, Capasso C, Carginale V, Riggio M, Capasso A, Ciaramella M, Filosa S, Parisi E (1997) PCR amplification and cloning of metallothionein complementary DNAs in 
temperate and Antarctic sea urchin characterized by a large difference in egg metallothionein content. Cell Mol Life Sci 53:472-477

Spataro V, Toda T, Craig R, Seeger M, Dubiel W, Harris AL, Norbury C (1997) Resistance to diverse drugs and ultraviolet light conferred by overexpression of a novel human $26 \mathrm{~S}$ proteasome subunit. J Biol Chem 272:30470-30475

Stanley PE, Kricka LJ (1990) Bioluminescence and chemiluminescence: current status. John Wiley \& Sons, New York

Thompson JD, Higgins DG, Gibson TJ (1994) CLUSTAL W: improving the sensitivity of progressive multiple sequence alignment through sequence weighting, positions-specific gap penalties and weight matrix choice. Nucleic Acids Res 22:4673-4680

Ugarkovic D, Kurelec B, Krca S, Batel R, Robitzki A, Müller WEG, Schröder HC (1990) Alterations in ras-gene expression and intracellular distribution of protein kinase $C$ in the sponge Geodia cydonium on response to marine pollution. Mar Biol 107:191-197

Unger ME, Chen TT, Murphy CM, Vestling MM, Fenselau C, Roesijadi G (1991) Primary structure of molluscan metallothioneins deduced from PCR-amplified cDNA and mass spectrometry of purified proteins. Biochim Biophys Acta 1074:371-377

Vogel S (1977) Current-induced flow through living sponges in nature. Proc Natl Acad Sci USA 74:2069-2071

Editorial responsibility: Otto Kinne (Editor),

Oldendorf/Luhe, Germany
Wagner C, Steffen R, Koziol C, Batel R, Lacorn M, Steinhart H, Simat T, Müller WEG (1998) Apoptosis in marine sponges: a biomarker for environmental stress (cadmium and bacteria). Mar Biol 131:411-421

Wiens M, Koziol C, Hassanein HMA, Batel R, Schröder HC, Müller WEG (1998) Induction of gene expression of the chaperones 14-3-3 and HSP70 by PCB $118\left(2,3^{\prime}, 4,4^{\prime}, 5-\right.$ pentachlorobiphenyl) in the marine sponge Geodia cydonium novel biomarkers for polychlorinated biphenyls. Mar Ecol Prog Ser 165:247-257

Wiens $M$, Seack J, Koziol C, Hassanein HMA, Steffen $R$, Korzhev M, Schröder HC, Batel R, Müller WEG (1999) $17 \beta$-estradiol-dependent regulation of chaperone expression and telomerase activity in the marine sponge Geodia cydonium. Mar Biol 133:1-10

Willuhn J, Schmitt-Wrede HP, Greven H, Wunderlich F (1994) cDNA cloning of a cadmium-inducible mRNA encoding a novel cysteine-rich, non-metallothionein $25-\mathrm{kDa}$ protein in an enchytraeid earthworm. J Biol Chem 269:24688-24691

Wilson R, Ainscough R, Anderson K, Baynes C, Berks M, Bonfield J, Burton J, Connell M, Copsey T, Cooper J and 44 coauthors (1994) $2.2 \mathrm{Mb}$ of contiguous nucleotide sequence from chromosome III of C. elegans. Nature 368:32-38

Zhou J, Goldsbrough PB (1995) Structure, organization and expression of the metallothionein gene family in Arabidopsis. Mol Gen Genet 248:318-328

Submitted: October 8, 1999; Accepted: December 16, 1999 Proofs received from author(s): June 21, 2000 